\title{
The Effect of Pozzolans and Mineral Wastes on Alkali-silica Reaction in Recycled Aggregated Mortar
}

\author{
Gökhan Külekçi $i^{1 *}$ \\ ${ }^{1}$ Gumushane University, Faculty of Engineering and Natural Sciences, Department of Mining Engineering, 29100 Gumushane, Turkey \\ * Corresponding author, e-mail: gkulekci@gumushane.edu.tr
}

Received: 14 October 2020, Accepted: 24 February 2021, Published online: 02 March 2021

\begin{abstract}
In this study, it was aimed to examine recycled aggregates (RA), which are considered as aggregates, in terms of alkali-silica reaction (ASR) before being used in concrete, to determine the risk status and to reduce the ASR value. In order to reduce and stop the ASR, the cement was replaced with clay brick and fly-ash by 10-40\%. Marble waste and Pb-Zn mine waste were used instead of RA in order to reduce aggregate reactivity. At the end of 28 days, compared to the control sample, it was observed that mortar bar samples containing tailings instead of fine RA has $18 \%$ less expansion and marble waste (MW) added samples again instead of fine RA has $34 \%$ less expansion. Furthermore, $40 \%$ fly ash (FA) added samples decreased the level of ASR for $96 \%$, and in $10 \%$ clay brick mixed samples ASR formation is decreased to $85 \%$. As a result, recycled aggregates were determined to be reactive for ASR. It has been determined that marble and lead-zinc mine facility wastes added as replace with to RA reduce the expansion effect by ASR in the cement paste. With this study, it has contributed to the safe use of the increasing use of RA in the world.
\end{abstract}

Keywords

alkali-silica reaction, construction and debris wastes, mineral wastes, pozzolans, recycled aggregates, waste management

\section{Introduction}

Recovering wastes of already used materials from different areas of utilization, after having them processed for a series of steps is called recycling [1]. The product which originates from deconstruction debris due to natural disasters, the broken concrete specimens obtained from concrete batching plants as a result of faulty production or the concrete parts which have to be cut and discarded during the production in the prefabrication is called the recycled aggregate (RA) [2]. The vast majority of the buildings around the world have reached the end of their service life. As a result of increasing population and earthquakes, there is a lot of deconstruction and urban transformation globally. The construction debris resulting from these demolitions poses numerous problems economically, environmentally and ecologically due to storage shortages and taxes [2, 3]. In addition to the problems caused by the waste, problems arise in the production of raw materials needed by the construction sector in parallel with the rapid global population growth. Recycled aggregate (RA) started to be used in order to eliminate the need for raw materials in construction sector and to eliminate construction wastes. Because of the fact that RA is taken from old structures and obscure production conditions of these structures, the future problems to be tackled in concrete production remain to be unknown. One of the biggest problems in concrete production is the formation of an alkaline silica reaction (ASR).

For the formation of ASR, there must be reactive silica in the aggregate, highly porous alkaline solution and sufficient humidity in the environment. Without any of these conditions, there will be no dilatation due to ASR. The amount of soft texture (gel) formed in concrete; depends on the type, amount and alkaline hydroxide concentration of silica $[3,4]$. In some cements alkaline oxides such as $\mathrm{K}_{2} \mathrm{O}$ and $\mathrm{Na}_{2} \mathrm{O}$ may be present in high concentrations. In the case where oxygen and active silica are present in the aggregate, then alkaline aggregate reaction leads to volume expansions. The $\mathrm{Na}, \mathrm{K}, \mathrm{Ca}$ silicate gel formed in this case expands into the mass of concrete and causes cracking. This event becomes apparent within two years of production. Due to its properties, silicate gel absorbs high amounts of water and causes an increase in gel volume. 
In some cases, this gel does not create damage by filling the gaps between the aggregates, but in other cases the expanded gel will bring out to too much intrinsic strain and cracks occur [5]. $85 \%$ of all the cement produced in Turkey are known to have low alkaline content. However, with the cement plants shifting from the wet production methods to the dry process, the alkaline content of the cements has increased significantly. Such that, the equivalent alkali content of the cements produced in 1996 is between $0.81 \%$ and $0.97 \%$. This figure has not changed significantly today [6]. In addition to cement alkalines, aggregates comprising some volcanic glasses, unwashed sea sand, altered feldspar, mica, clay and zeolite also contribute to the alkaline level of the concrete cavity solution [7]. Clay minerals in limestone aggregate and feldspar rich aggregates increase the alkaline level of cavity solution of some basalts and in mixtures with high aggregate content with water/cement ratio $[5,8]$. Many different methods are used to measure and detect the alkaline silica reaction [9]. Furthermore, in order to prevent the formation of ASR, the mechanism, process and chemical structure of ASR have been investigated by many researchers [10]. In these investigations, it has been demonstrated that the use of mineral additives improves compression resistance, permeability and void structure of mortar and concrete over time [11]. It is known that the total cavity ratio of concrete or mortar is reduced by the hydration process and mineral admixtures such as silica fume and fly ash also reduce ASR expansion [12]. Pozzolans are also widely preferred in concrete mixtures for the same purpose. Pozzolans reduce the $\mathrm{pH}$ of the environment by binding the free lime in the cement mortar. In addition to this, they reduce the solubility of the silica and prevent the formation of ASR and gel. Another advantage of pozzolans for ASR is that they increase the impermeability of concrete or mortar $[13,14]$. Various studies have been carried out to reduce ASR by using different mineral additives in the mixture. In one study, it was reported that fly ash reduced the expansion of ASR $[15,16]$. While many researchers have attempted to prevent the formation of ASR by adding or substituting pozzolans instead of cement, very few researchers have used $\mathrm{pH}$ reducing aggregates instead of aggregates [17]. In most of the studies, natural aggregates were used and the substitutions were made into cement. A small number of studies used RA alone, while in a very small number of them a second aggregate were used. In the studies, materials of pozzolan nature or not, such as broken bricks or glass were tried and many details were examined. In order to reduce the risk of ASR in the RA, no studies have been found regarding the use of high- $\mathrm{Ph}$ marble waste or low $\mathrm{pH}$ tailings. For this purpose, reactivity of the RA is investigated by means of rapid mortar method whether it is recycled from the building debris which is estimated to be produced from sea sand, stream aggregate or old high alkali ratio cement. Besides, two different paths were followed in order to decrease the amount of ASR gel and to make it harmless. At first pozzolans such as clay brick and fly ash are replaced for cement. For the second, instead of the fine aggregate used in RA, the marble waste obtained from the marble processing plants and the zinc-lead waste from the metallic mineral processing plants were added and the results were examined. The mechanism and process of ASR gel formation were evaluated via SEM analysis.

\section{Material}

\subsection{Recycled aggregate}

Recycled aggregate (RA) used within the scope of the study, consists of building wastes whose economic life was completed or demolished for urban transformation. They are originated from eastern Turkey, northern Ordu, Trabzon and Gumushane provinces (Fig. 1).

Within the framework of the study, the construction debris from different places was subjected to size reduction process for ASR experiments.

The debris was brought to aggregate size by reducing their size. Then sieve analysis was performed by using a folded sieve to determine the class of recycled aggregates (RA). After the construction debris wastes from 9 different locations were converted to RA, density, water absorption, porosity and freezing dissolution tests were run. Experiment results also given in Table 1.

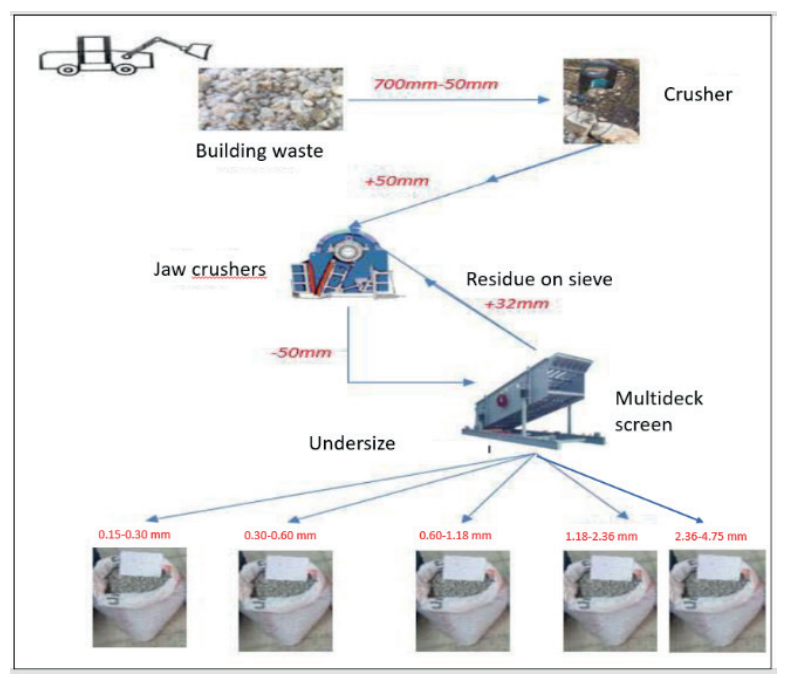

Fig. 1 Flow diagram of construction of sample from building waste 
Table 1 Physical properties of recycled aggregate

\begin{tabular}{lc}
\hline Name of physical property & \\
\hline Particle density, g/cm & \\
Water absorption, \% & 1.92 \\
Porosity, \% & 10.13 \\
Freeze-thaw, \% & 19.46 \\
\hline
\end{tabular}

\subsection{Cement}

In the study CEM I 42.5 R (TS EN 197-1) class cement used as binding material. Chemical, physical and pressure properties of cement are shown in Table 3 [18]. The $\left(\mathrm{Na}_{2} \mathrm{O}+0.658 \mathrm{~K}_{2} \mathrm{O}\right)$ value, which is called the equivalent alkali content that affects the formation of ASR due to cement, was calculated to be $0.53 \%$. The equivalent alkali content has to be more than $0.6 \%$ to lead to an ASR. As the specimens are kept in solutions that include much more alkali than required to effect ASR, the alkali content of the cement is not important [19,20].

\subsection{Pozzolans (fly ash, clay brick)}

In this study, as pozzolan additive C-class fly ash obtained from thermal power plant and brick clay from the brick factory are used (Fig. 2).

\subsubsection{Fly ash}

The fly ash used in this study, were obtained from AfşinElbistan thermal power plant in Turkey-Kahramanmaras. For use as a pozzolan, it is used by grinding to a size compatible to granulometry of Fig. 3. Chemical properties of fly ash also given in Table 2.

\subsubsection{Clay brick}

In the study, clay brick obtained from brick waste was used. Brick waste was milled for 90 minutes in dry mill and reduced in size. The granulometric properties of milled baked clay are shown in Fig. 3. After milling, according to TS EN 196-2 and TS EN 196-6' the physical, chemical and mineralogical characterization of the materials was carried out [21]. Chemical, physical and mineralogical properties of clay brick and fly ash are given in Table 2 and Table 3. XRD results of clay brick used in the study are given in Fig. 4. As a result of XRD analysis, Al, Q, H and Il minerals were found in clay brick.

\subsection{Waste material (tailing and marble waste)}

In this study, aggregates such as marble waste taken from the saw blade of marble processing plants and the tailing of the lead zinc processing plant were used instead of the

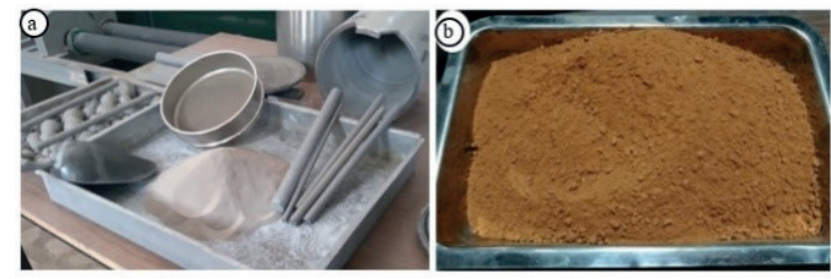

Fig. 2 (a) Fly ash and (b) Clay brick, ball and bar mill with the help of the appropriate size

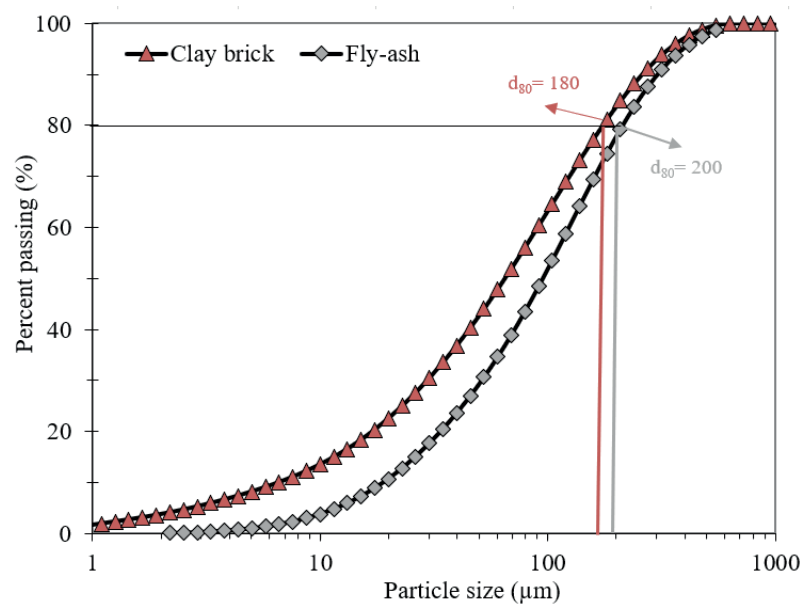

Fig. 3 Clay brick and fly ash grain size distribution

Table 2 Chemical compositions of fly-ash ground crushed brick and cement

\begin{tabular}{lccc}
\hline & \multicolumn{3}{c}{ Chemical component (\%) } \\
& Clay brick & Fly ash & Cement \\
\hline $\mathrm{SiO}_{2}$ & 69.01 & 23.08 & 18.59 \\
$\mathrm{Al}_{2} \mathrm{O}_{3}$ & 14.66 & 6.25 & 4.69 \\
$\mathrm{Fe}_{2} \mathrm{O}_{3}$ & 4.60 & 2.58 & 3.04 \\
$\mathrm{MgO}$ & 1.60 & 1.6 & 1.92 \\
$\mathrm{CaO}$ & 3.11 & 47.03 & 60.34 \\
$\mathrm{Na}$ & 1.94 & 0.32 & 0.11 \\
$\mathrm{~K}_{2} \mathrm{O}$ & 2.34 & 0.47 & 0.64 \\
$\mathrm{LOI}^{*}$ & 1.8 & 3.95 & 7.19 \\
\hline
\end{tabular}

"Loss of ignition

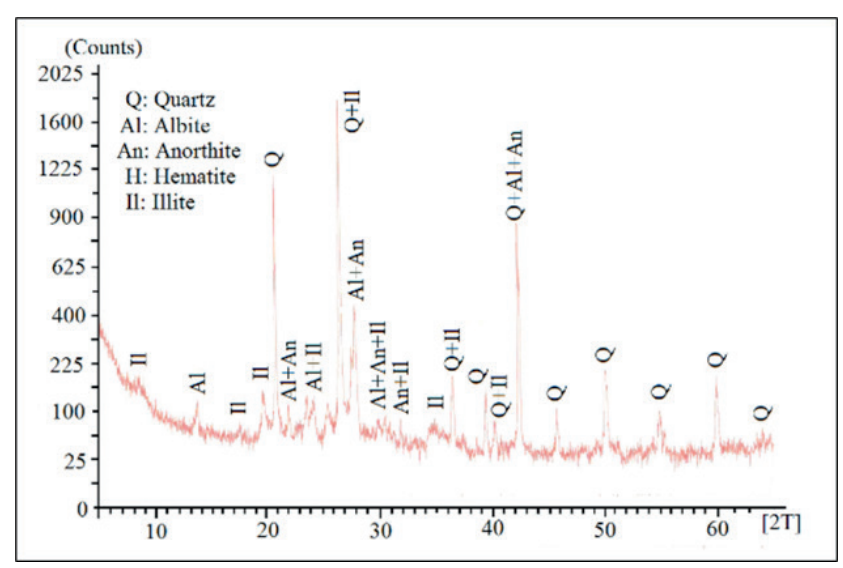

Fig. 4 XRD analysis of clay brick [20] 
fine RA. In order to reduce the effect of alkali-silica reaction in recycled aggregate (RA), $10 \%$ mine waste and marble waste, were used instead of fine aggregate in the ASR experiment. In literature studies, it was revealed that ASR formation was at high $\mathrm{pH}$ and ASR could be prevented if $\mathrm{pH}$ levels would decrease [22]. However, marble wastes with high $\mathrm{CaCO}_{3}$ content were used in this study. The reason for this is that the marble waste used will reduce the amount of reactive aggregate and thus ASR formation. Chemical analysis of the wastes is given in Table 4.

Table 3 Basic physical properties of the fly-ash, cement and ground crushed brick

\begin{tabular}{lccc}
\hline & \multicolumn{3}{c}{ Physical properties } \\
& Clay brick & Fly ash & Cement \\
\hline Specific gravity $\left(\mathrm{g} / \mathrm{cm}^{3}\right)$ & 2.68 & 2.44 & 3.05 \\
Specific surface area $\left(\mathrm{cm}^{2} / \mathrm{g}\right)$ & 5670 & 2496 & 4145 \\
Grinding time (min.) & 15 & 30 & - \\
7 days pozzolanic activity $(\mathrm{MPa})$ & 9.3 & 15.8 & \\
Degree of calcination $\left(0^{\circ} \mathrm{C}\right)$ & $700-800$ & & $800-1000$ \\
Reactive $\mathrm{SiO}_{2}(\%)$ & 17.75 & & \\
Glassy phase content $(\%)$ & 55.15 & & \\
\hline
\end{tabular}

Table 4 Chemical compositions of tailing and marble

\begin{tabular}{lcc} 
& \multicolumn{2}{c}{ Chemical component $(\%)$} \\
& Tailing & Marble \\
\hline $\mathrm{Pb}$ & 0.33 & $<0.01$ \\
$\mathrm{Zn}$ & 0.96 & $<0.01$ \\
$\mathrm{Fe}$ & 4.78 & 0.1 \\
$\mathrm{Al}$ & 0.4 & 0.53 \\
$\mathrm{Si}$ & 1.3 & 1.16 \\
$\mathrm{~S}$ & 2.84 & - \\
$\mathrm{K}$ & 0.11 & 0,1 \\
$\mathrm{Ca}$ & 19.77 & 55.12 \\
$\mathrm{Ti}$ & 0.05 & 0.01 \\
\hline L & &
\end{tabular}

* Loss of ignition

\section{Method}

Accelerated mortar bar test was performed according to ASTM C 1260 standard in order to determine the ASR on the RA samples and to examine the effect of the pozzolans [23].

\subsection{Alkaline silica test (fast mortar bar method)}

32 mortar bars were prepared $(25 \times 25 \times 285 \mathrm{~mm})$ for determining ASR development on recycled aggregates. Pozzolans, fly ash and clay bricks are replaced $10 \%$ and $40 \%$ to the cement wastes such as marble waste, waste from the ore processing tailing that were sieved number 50 , constitute $15 \%$ of the aggregate mixture amount. Mortar bar mixing ratios are shown in Table 5.

\subsubsection{Preparation of mortar bars}

Mortar Bars are prepared according to the principles specified in (ASTM C-227) and (ASTM C-1260). Mixture water/cement ratios are determined according to the principles stated in ASTM C 109 "Test Method for Compressive Strength of Hydraulic Cement Mortars" [23]. Mixture ratios and amounts used in preparation of mortar bars are also given in Table 6.

\section{Results and discussion}

As a result of the accelerated mortar bar tests run on 28 mortar bars, the length change values of the samples were determined (Fig. 5). Four samples were prepared for each

\begin{tabular}{lcc}
\multicolumn{3}{c}{ Table 5 Grading of aggregates } \\
\hline \multicolumn{2}{c}{ Opening of a mesh, mm } & $\begin{array}{c}\text { Percentage by } \\
\text { weight, } \%\end{array}$ \\
\hline $4.75($ No.4) & Undersize & 10 \\
2.36 (No.8) & $2.36($ No.8) & 25 \\
$1.18($ No.16) & $1.18($ No.16) & 25 \\
$0.60($ No.30) & $0.60($ No. .30$)$ & 25 \\
$0.30($ No. 50$)$ & $0.30($ No. .50$)$ & 15 \\
\hline
\end{tabular}

Table 6 Mixture proportions of specimens used in the experiment

\begin{tabular}{|c|c|c|c|c|c|c|c|c|c|c|}
\hline Mix ID & $\begin{array}{c}\text { Number of } \\
\text { samples }\end{array}$ & $\begin{array}{c}\text { Natural } \\
\text { aggregate (gr) }\end{array}$ & RA (gr) & $\begin{array}{l}\text { Cement } \\
\text { (gr) }\end{array}$ & $\begin{array}{c}\text { Clay } \\
\text { Brick (gr) }\end{array}$ & $\begin{array}{l}\text { Fly ash } \\
\text { (gr) }\end{array}$ & $\begin{array}{l}\text { Marble } \\
\text { (gr) }\end{array}$ & $\begin{array}{l}\text { Tailing } \\
\text { (gr) }\end{array}$ & $\mathrm{W} / \mathrm{C}$ & $\begin{array}{c}\text { Water } \\
(\mathrm{ml})\end{array}$ \\
\hline RA (Control) & 4 & 0 & 1000 & 444 & 0 & 0 & 0 & 0 & 0.5 & 222 \\
\hline $\mathrm{RA}+\mathrm{CB} 10$ & 4 & 0 & 1000 & 399.6 & 44.4 & 0 & 0 & 0 & 0.5 & 222 \\
\hline $\mathrm{RA}+\mathrm{CB} 40$ & 4 & 0 & 1000 & 266.4 & 177.6 & 0 & 0 & 0 & 0.5 & 222 \\
\hline $\mathrm{RA}+\mathrm{FA} 10$ & 4 & 0 & 1000 & 399.6 & 0 & 44,4 & 0 & 0 & 0.5 & 222 \\
\hline $\mathrm{RA}+\mathrm{FA} 40$ & 4 & 0 & 1000 & 266.4 & 0 & 177.6 & 0 & 0 & 0.5 & 222 \\
\hline $\mathrm{RA}+\mathrm{MR} 10$ & 4 & 0 & 900 & 444 & 0 & 0 & 100 & 0 & 0.5 & 222 \\
\hline $\mathrm{RA}+\mathrm{T} 10$ & 4 & 0 & 900 & 444 & 0 & 0 & 0 & 100 & 0.5 & 222 \\
\hline
\end{tabular}

RA: Recovered aggregate, CB: Clay brick, FA: Fly ash, MR: Marble, T: Tailing 
mixture ratio. Average of the measures in 7-14-28 days are taken into account (Table 7). In the study, it was observed that the reference mortar bars prepared with recycled aggregate had a height increase of $0.23 \%$ at the end of 28 days. It was determined that high percentage of sea sand and river aggregates were used in the concretes where RA was supplied and this has an effect in the formation of ASR formation. In the studies conducted in the literature, ASR formation was observed in the mixtures with RA and different methods were proposed against the formation.

The mortar mixtures prepared using RA were determined to have reduced length change $(0.007 \%)$ due to the pozzolans added as substitutes for cement. Also, it is determined that usage of reactive non-aggregated marble waste and acidic tailing instead of fine RA affects the formation of ASR.

Explanatory statistics on the results of 28 accelerated mortar bar test results are given in Table 8 .

Length changes of fly ash added mortar bars are given in Fig. 6. Fig. 6 in the evaluation of reference RA and fly ash (FA) added mortar samples, It was determined that the 7-day length change values of the reference samples were
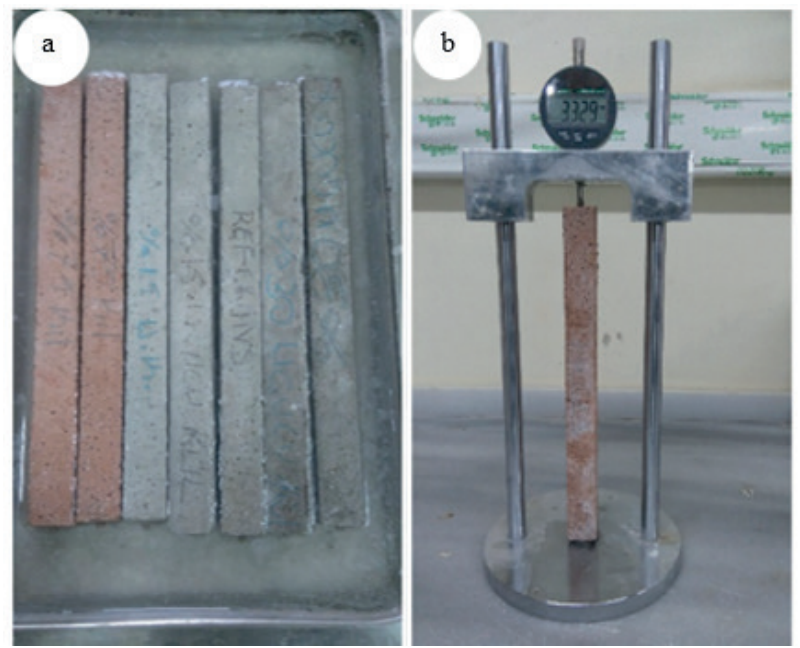

Fig. 5 Accelerated mortar bar test

Table 7 Average expansion amount of mortar bars

\begin{tabular}{lccc}
\hline Mix ID & \multicolumn{3}{c}{ Mean (\%) } \\
\hline RA (Control) & 0.043 & 0.145 & 0.231 \\
RA + FA10 & 0.003 & 0.005 & 0.016 \\
RA + FA40 & 0.000 & 0.001 & 0.007 \\
RA + CB10 & 0.010 & 0.033 & 0.047 \\
RA + CB40 & 0.076 & 0.085 & 0.092 \\
RA + MW10 & 0.050 & 0.103 & 0.142 \\
RA + T10 & 0.097 & 0.136 & 0.179 \\
\hline
\end{tabular}

at the risky area with the alkali silica reaction (ASR) of $0.145 \%$, and at the end of the $28^{\text {th }}$ day, with a change of $0.231 \%$, the RA was found to be risky for the alkaline silica reaction. For fly ash added mortar samples, it was observed that the increase in fly ash amount decreased the size change. At the end of 28 days of $40 \%$ fly ash added

Table 8 Explanatory statistics on experiment results

\begin{tabular}{|c|c|c|c|c|c|}
\hline $\begin{array}{l}\text { Sample } \\
\text { code }\end{array}$ & $\begin{array}{c}\text { Num. of } \\
\text { samp. }\end{array}$ & $\begin{array}{c}\text { Arith. mean } \\
\qquad(\%)\end{array}$ & $\begin{array}{l}\text { Standard } \\
\text { deviation }\end{array}$ & $\begin{array}{c}\text { Min. } \\
(\%)\end{array}$ & $\begin{array}{l}\text { Max. } \\
(\%)\end{array}$ \\
\hline \multicolumn{6}{|c|}{7 days } \\
\hline RA & 4 & 0.04324 & 0.03295 & 0.010 & 0.076 \\
\hline FA10 & 4 & 0.00310 & 0.00255 & 0.001 & 0.005 \\
\hline FA40 & 4 & 0.00044 & 0.00009 & 0.001 & 0.001 \\
\hline CB10 & 4 & 0.01000 & 0.00436 & 0.005 & 0.013 \\
\hline CB40 & 4 & 0.07612 & 0.00767 & 0.069 & 0.084 \\
\hline MW10 & 4 & 0.05020 & 0.04596 & 0.010 & 0.100 \\
\hline TW10 & 4 & 0.09670 & 0.04255 & 0.054 & 0.139 \\
\hline \multicolumn{6}{|c|}{14 days } \\
\hline RA & 4 & 0.14500 & 0.02831 & 0.124 & 0.177 \\
\hline FA10 & 4 & 0.00516 & 0.00503 & 0.001 & 0.010 \\
\hline FA40 & 4 & 0.00120 & 0.00072 & 0.001 & 0.002 \\
\hline CB10 & 4 & 0.03313 & 0.00999 & 0.023 & 0.043 \\
\hline CB40 & 4 & 0.08526 & 0.02217 & 0.064 & 0.108 \\
\hline MW10 & 4 & 0.10353 & 0.06355 & 0.040 & 0.167 \\
\hline TW10 & 4 & 0.13577 & 0.05475 & 0.081 & 0.190 \\
\hline \multicolumn{6}{|c|}{28 days } \\
\hline RA & 4 & 0.23143 & 0.12667 & 0.110 & 0.363 \\
\hline FA10 & 4 & 0.01590 & 0.01239 & 0.009 & 0.030 \\
\hline FA40 & 4 & 0.00750 & 0.00535 & 0.002 & 0.013 \\
\hline CB10 & 4 & 0.04657 & 0.04968 & 0.004 & 0.101 \\
\hline CB40 & 4 & 0.09227 & 0.05805 & 0.034 & 0.150 \\
\hline MW10 & 4 & 0.14170 & 0.05998 & 0.085 & 0.204 \\
\hline TW10 & 4 & 0.17867 & 0.05420 & 0.124 & 0.233 \\
\hline
\end{tabular}

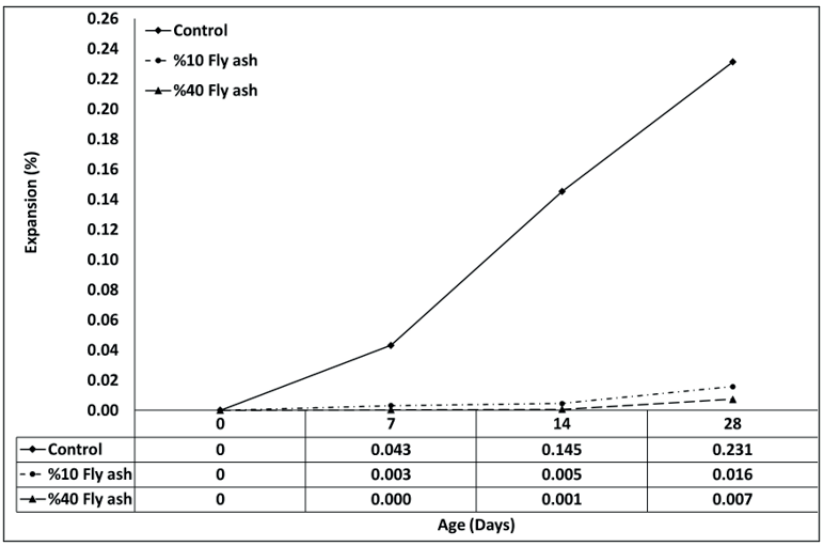

Fig. 6 Expansion values of fly ash additive mortar bars 
samples showed $96 \%$ less ASR formation. The main reason behind this is the alkaline binding property of fly ash. Thanks to its alkaline bonding property, it decreases the $\mathrm{C} / \mathrm{S}$ ratio in the $\mathrm{C}-\mathrm{S}-\mathrm{H}$ gel formed between cement and aggregate, thus decreasing its alkalinity, consequently preventing the formation of ASR gel [24, 25]. Besides, the fly ash increases the tensile strength of the mortar bars and the ASR gel will form cracks in a slower rate. Stopping or slowing down crack formation also slows $\mathrm{NaOH}$ passage from crack to sample [21]. Length changes of mortar bars due to replacement of clay bricks instead of binder are given in Fig. 7. It has been found out that the samples containing clay brick added mortar have reduced expansion by the ASR. The least expansion was determined in $10 \%$ clay brick mixed samples.

It was determined that the use of milled clay bricks instead of cement significantly modified the chemical composition of ASR gel and reduced its viscosity, which significantly reduced the formation of ASR. Sodium and potassium oxides in cement are caused by the raw materials (clay, limestone, shale etc.) of cement. Also, alkalines may show presence except cement; through aggregate, mixing water, concrete additives, de-icing salts, ground water, concrete curing water and industrial wastewater [4]. Excess of external influences and increased equivalent $\mathrm{Na}_{2} \mathrm{O}$ value will increase formation of ASR thus increasing the length. When the sodium oxide equivalent of clay bricks and fly ash in cement is calculated, the highest value belongs to the clay brick (Table 9). ASR formation will increase as the quantity of the clay brick increases. Instead of fine aggregate, it was tried to reduce the formation of ASR gel in the RA, by using marble waste and tailing which is reactive in the fast mortar test. For this purpose, wastes with different chemical structure and $\mathrm{pH}$ levels were used instead of fine RA. Fig. 8 As seen in, at

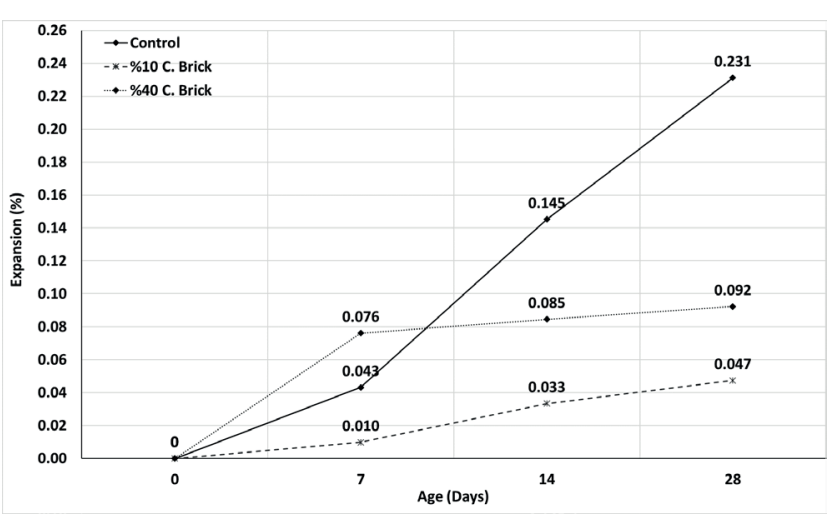

Fig. 7 Expansion values of clay brick additive mortar bars the end of 28 days, marble waste and tailing used instead of thin RA decreased ASR formation. The mortar bars prepared with marble wastes (MW) $33.65 \%$ less and with tailing $19 \%$ less length increase after 28 days compared to the control samples. Due to the reduction of aggregate content containing reactive silica and substitution of marble wastes to RA as aggregate, ASR formation is decreased. In the first 7 days, the maximum elongation was in the tailings (TW). The high metal content of the tailings reduced the $\mathrm{pH}$ of the TW. The alkali-silica reaction depends on the alkaline concentration and aggregate reactivity. In order for the ASR reaction to occur, the $\mathrm{pH}$ of the concrete should be sufficiently high and a sufficient amount of concrete alkalines must be present in the concrete mixture. The level of reactivity of silica is defined as the $\mathrm{pH}$ threshold for the first reaction. After the start of ASR, it will continue until reactive silica is depleted, the $\mathrm{pH}$ of the solution is lowered below the desired threshold or the moisture in the concrete mass is exhausted [26]. For this reason, the TW used instead of fine RA which has an acidic structure, the formation of ASR increased very rapidly in the first 7 days and then continued to increase slowly.

As the reactive silica dissolves at high $\mathrm{pH}$, the formation of ASR occurs at high $\mathrm{pH}$ values.

At the end of 28 days, compared to the control sample, it was observed that mortar bar samples containing tailings instead of fine RA has $18 \%$ less expansion and

Table 9 Equivalent $\mathrm{Na}_{2} \mathrm{O}$ of additives

\begin{tabular}{lcccccc}
\hline & \multicolumn{2}{c}{ Chemical component (\%) } & \multicolumn{3}{c}{ *Equivalent $\mathrm{Na}_{2} \mathrm{O}$} \\
& $\begin{array}{c}\text { Clay } \\
\text { brick }\end{array}$ & Fly ash & Cement & $\begin{array}{c}\text { Clay } \\
\text { brick }\end{array}$ & Fly ash & Cement \\
\hline $\mathrm{Na}_{2} \mathrm{O}$ & 1.94 & 0.32 & 0.11 & 3.480 & 0.629 & 0.531 \\
$\mathrm{~K}_{2} \mathrm{O}$ & 2.34 & 0.47 & 0.64 & & & \\
\hline
\end{tabular}

$*\left(\mathrm{Na}_{2} \mathrm{O}\right) \mathrm{e}=\mathrm{Na}_{2} \mathrm{O}+0.658 \mathrm{~K}_{2} \mathrm{O}$

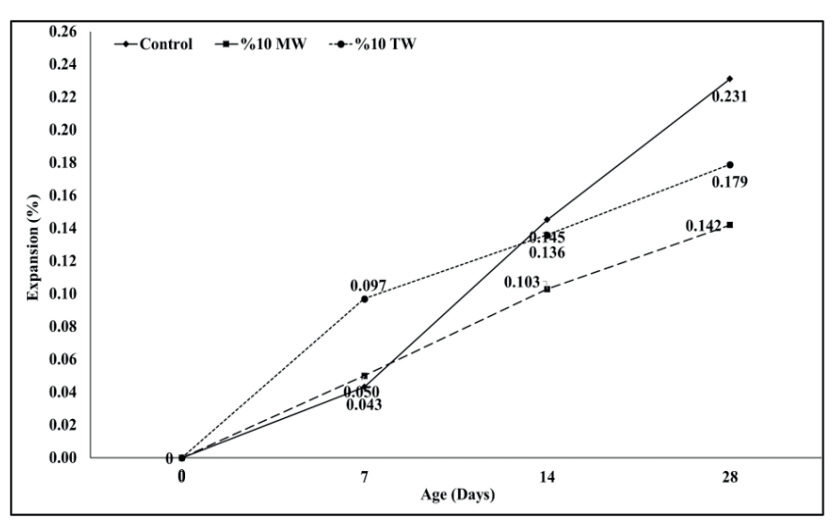

Fig. 8 Expansion values of marble and tailing additive mortar bars 
marble waste (MW) added samples again instead of fine RA has $34 \%$ less expansion. Furthermore, $40 \%$ fly ash (FA) added samples decreased the level of ASR for $96 \%$, and in $10 \%$ clay brick mixed samples ASR formation is decreased to $85 \%$ (Fig. 9). Chemical structure of the additives used to reduce the reactivity of RA and prevent the formation of ASR gel, $\mathrm{Ca} / \mathrm{Si}$ ratio and total expansion at the end of 28 days given found in Table 10.

The high level of calcium in the components increases the viscosity of the formed ASR gel and allows it less movement $[27,28]$. Regarding the additives as a pozzolan, it was determined that the contribution of cement to the ASR gel was significantly reduced. In the chemical structure of the additives brought to the cement size by milling, it was found out that a high degree of $\mathrm{Al}$ is present. This component transformed CSH gel into CASH gel as a result of reaction during the cement hydration process and it was stable in structure [24, 29-33]. Considering the ground pozzolans are rich in alumina, C-A-S-H gel has the potential to trap alkaline ions. Therefore, due to the alkalines restrained by the C-S-H gel, the formation of ASR will decrease as the alkali ion required for the formation of ASR gel was reduced in the mixture $[33,34]$. In the study performed with mineral microscopy, 18 fine section samples taken from the concrete prepared for ASR experiments, show clearly the
Table 10 The effect of chemical structure of samples on expansion

\begin{tabular}{lcccccc}
\hline \multirow{2}{*}{ Sample } & \multicolumn{5}{c}{ Chemical composition (\%) } & Expansion rate \\
& $\mathrm{Ca}$ & $\mathrm{Si}$ & $\mathrm{K}$ & $\mathrm{Al}$ & $\mathrm{Ca} / \mathrm{Si}$ & after 28 days (\%) \\
\hline Cement & 60.34 & 18.59 & 0.64 & 4.69 & 3.25 & 0.211 \\
TW & 19.77 & 1.3 & 0.11 & 0.4 & 15.21 & 0.173 \\
MW & 55.12 & 1.16 & 0.1 & 0.53 & 47.52 & 0.140 \\
C. brick & 3.11 & 69.01 & 2.34 & 14.66 & 0.04 & 0.030 \\
F. ash & 47.03 & 23.08 & 0.47 & 6.25 & 2.04 & 0.008 \\
\hline
\end{tabular}

formation of ASR gel. In the images, it is seen that the previous cement occupies the aggregate surface and sometimes it penetrates. It is seen that the new cement used as a binder interconnects the aggregates but cannot enter the cavities formed by the cement. ASR gel formation was observed in the cavities formed by cement (Fig. 10). SEM analysis was performed on the samples in order to view the ASR formation mechanism and its properties in more detail. As a result of the SEM analysis, ASR gel which is formed in cement paste and on aggregate surfaces and the resulting cavities/cracks may be observed. Some sources indicate that, according to XRD analysis the ASR gel is similar to the zeolite with the composition of $\left(\mathrm{NaAlSiO}_{4}\right) 12.27 \mathrm{H}_{2} \mathrm{O}$ or $\mathrm{Ca}\left(\mathrm{Al}-\mathrm{SiO}_{4}\right) 12.27 \mathrm{H}_{2}$ determined [25, 28, 35, 36]. Also on ASR Gel and crystal products are formed on aggregate, mortar interface and air voids (Fig. 11).

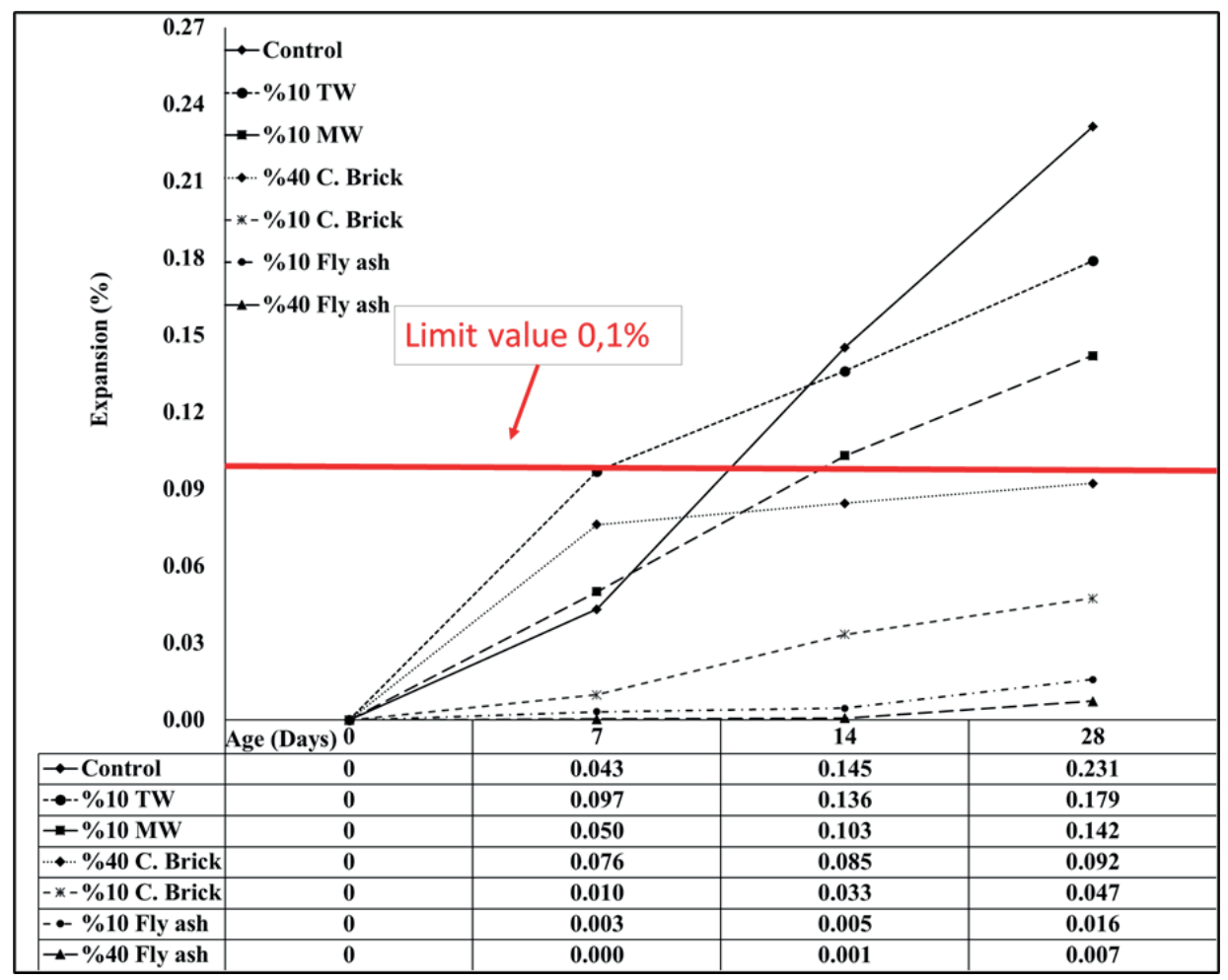

Fig. 9 Effects of cement and recovered aggregate admixtures on ASR 


\section{Conclusions}

In order to find the alkaline silica reaction, a fast mortar bar method was applied on RAs. Experiments show that, at the end of 14 days reference samples have an expansion value which are at the critical area. As conclusion, aggregates obtained from waste construction concrete are considered to be potentially harmful. According to ASTM C1260, the duration of the test duration was extended to 28 days and at the end of 28 days it was determined that the length change values of the samples were risky for ASR, but the fly ash additive and clay brick additive samples showed decreased expansion values which are less than $0.1 \%$. The resulting pozzolanic reactions decreased mortar permeability, decreased water penetration and stop the expansion of ASR gel. This finding supports previous literature studies. When clay bricks were used as pozzolan, it was determined that $10 \%$ replaced samples were more effective in inhibiting ASR than $40 \%$ replaced clays. The increase in substitution rate and the increase in ASR expansion are directly related to the chemical composition of clay. It was observed that ASR expansion increased as the equivalent sodium amount

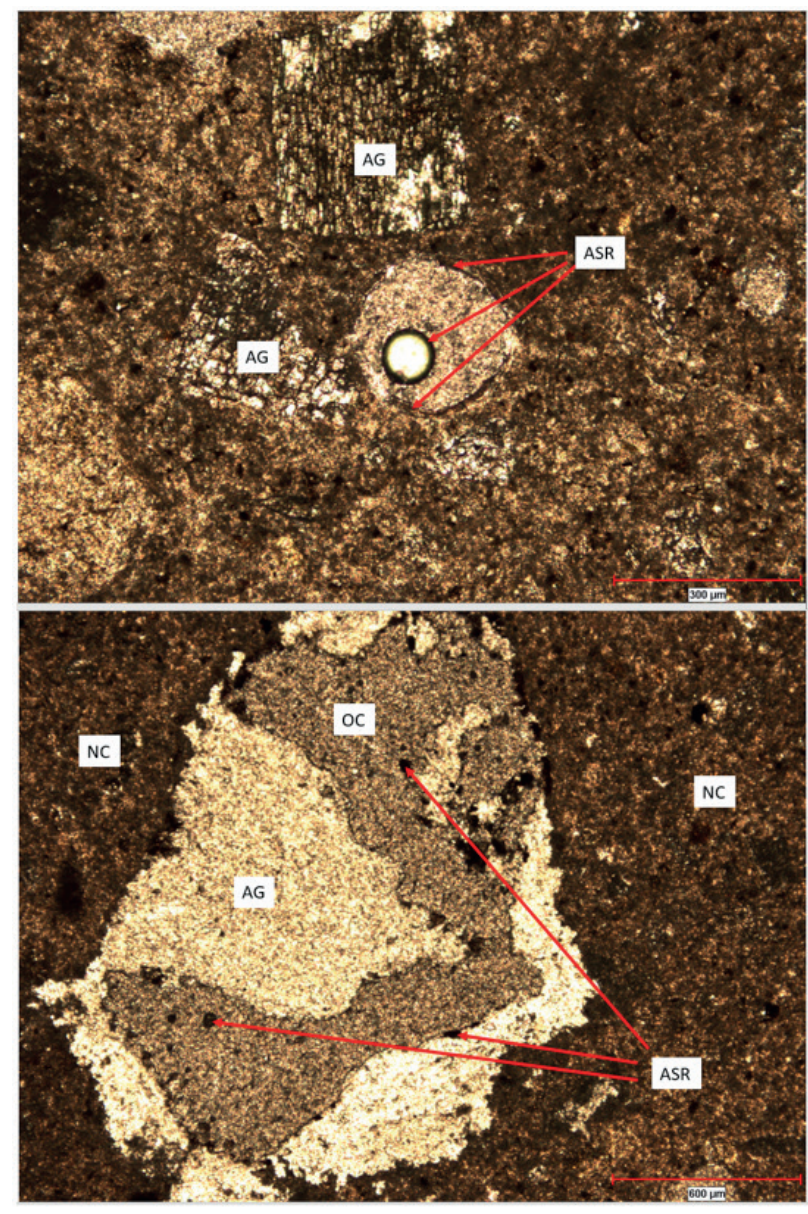

Fig. 10 Images of mortar bar under the mineral microscope (ASR: alkali silica gel, AG: aggregate, $\mathrm{NC}$; new cement, OC: old cement) of baked clay increased. In the preparation of the mortar samples of the ASR experiment, the use of marble waste and tilling instead of RA with $150 \mu \mathrm{m}-300 \mu \mathrm{m}$ range was determined to produce reduced ASR expansions. Aggregate granulometry is important for ASR formation. In the study, it was observed that aggregate size was effective in reducing ASR in waste. In addition, due to the acidic nature of the tilling, the $\mathrm{pH}$ of the gap solution was reduced, slowing down the formation of ASR. ASR occurs at high $\mathrm{pH}$ values, as the reactive silica is soluble in high $\mathrm{pH}$ solution. In order to reduce the reactivity of recycled aggregate (RA), which is reactive in terms of ASR, different substances were used instead of fine aggregate and cement. It has been observed that the marble waste and tilling used in place of the fine RA slows down the ASR expansion but is not as effective as the pozzolan addition to the cement.

With this study, ASR formation on RA was revealed and pozzolanes preventing ASR formation were proposed. In addition, alternative areas of use have been revealed for dam waste and marble waste, which cause major environmental problems as waste.

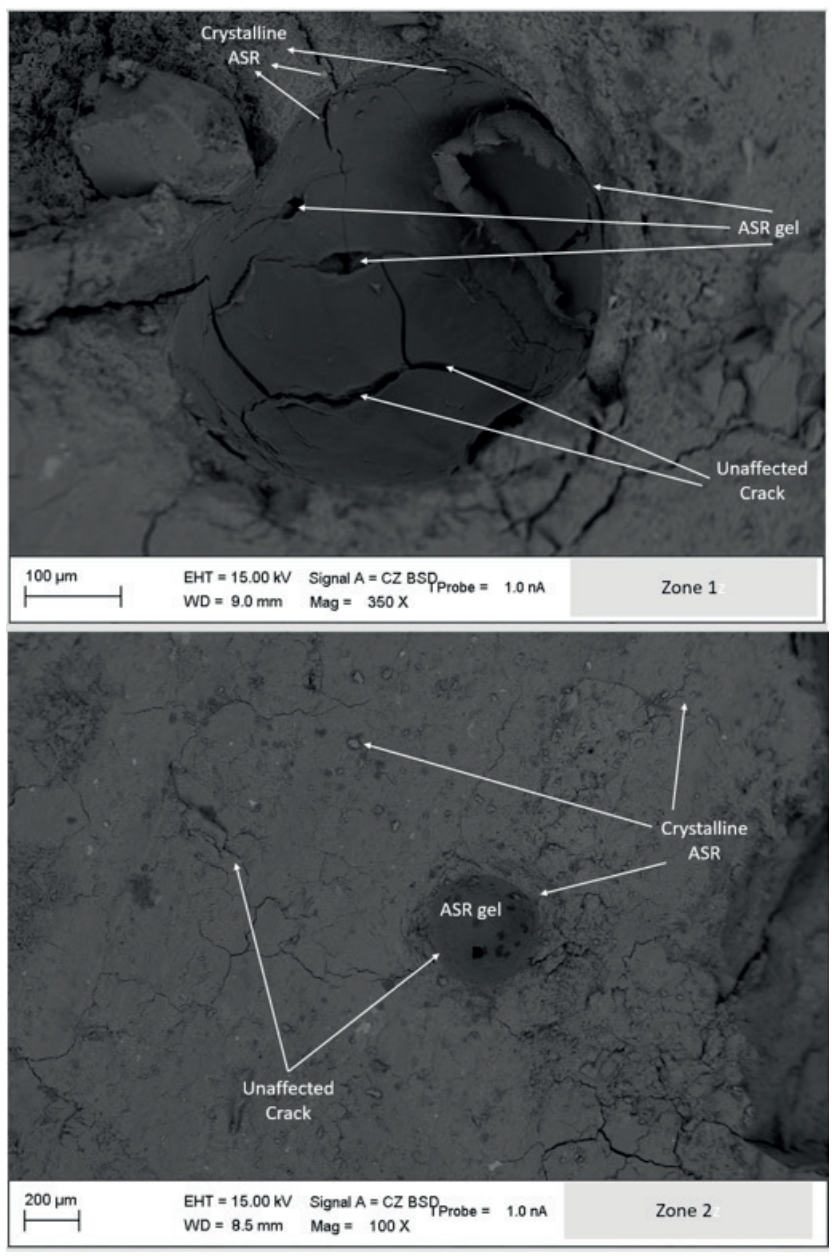

Fig. 11 Image of mortar bars as a result of SEM analysis 


\section{Acknowledgment}

The author expresses her sincere thanks and thanks to Doç. Dr. Mustafa ÇULLU and his students for their contribution and assistance to this study.

\section{References}

[1] Külekçi, G. "Investigation of the Utilization Areas of Construction and Demolition Wastes in The Black Sea Region Instead of Aggregate and Their Areas of Usage in the Mining Industry", $\mathrm{PhD}$ Thesis, Karadeniz Technical University, 2018.

[2] Cabrera-Covarrubias, F. G., Gómez-Soberón, J. M., AlmaralSánchez, J. L., Corral-Higuera, R., Gómez-Soberón, M. C. "Implementation of Interaction Diagram of the Properties in Fresh for Mortars with Ceramic Aggregates", Periodica Polytechnica Civil Engineering, 61(2), pp. 335-340, 2017. https://doi.org/10.3311/PPci.9651

[3] Chandra, S. "Implications of using recycled construction and demolition waste as aggregate in concrete", In: International Conference on Sustainable Waste Management and Recycling, Kingston University, London, UK, 2004, pp. 105-114.

[4] Grattan-Bellew, P. E. "Laboratory Evaluation of Alkali-Silica Reaction in Concrete from Saunders Generating Station", ACI Materials Journal, 92(2), pp. 126-134, 1995. https://doi.org/10.14359/9763

[5] Duchesne, J., Bérubé, M. A. "The effectiveness of supplementary cementing materials in suppressing expansion due to ASR: Another look at the reaction mechanisms part 2: Pore solution chemistry", Cement and Concrete Research, 24(2), pp. 221-230, 1994. https://doi.org/10.1016/0008-8846(94)90047-7

[6] Islam, M. S., Ghafoori, N. "A new approach to evaluate alkali-silica reactivity using loss in concrete stiffness", Construction and Building Materials, 167, pp. 578-586, 2018. https://doi.org/10.1016/j.conbuildmat.2018.02.047

[7] Lahdensivu, J., Kekäläinen, P., Lahdensivu, A. "Alkali-silica Reaction in Finnish Concrete Structures", Nordic Concrete Research, 59(2), pp. 31-44, 2018. https://doi.org/10.2478/ncr-2018-0013

[8] Ling, T.-C., Balachandran, C., Munoz, J. F., Youtcheff, J. "Chemical evolution of alkali-silicate reaction (ASR) products: a Raman spectroscopic investigation", Materials and Structures, 51, Article No. 23, 2018. https://doi.org/10.1617/s11527-018-1151-X

[9] Visser, J. H. M. "Fundamentals of alkali-silica gel formation and swelling: Condensation under influence of dissolved salts", Cement and Concrete Research, 105, pp. 18-30, 2018. https://doi.org/10.1016/j.cemconres.2017.11.006

[10] Bágel, L. "Strength and pore structure of ternary blended cement mortars containing blast furnace slag and silica fume", Cement and Concrete Research, 28(7), pp. 1011-1022, 1998. https://doi.org/10.1016/S0008-8846(98)00078-7

[11] Dongxue, L., Xinhua, F., Xuequan, W., Mingshu, T. "Durability study of steel slag cement", Cement and Concrete Research, 27(7), pp. 983-987, 1997.

https://doi.org/10.1016/S0008-8846(97)00084-7

\section{Research data for this article}

All data generated or analyzed during this study are included in this published article. The author declares that there is no conflict of interest regarding the publication of this paper.

[12] Monteiro, P. J. M., Wang, K., Sposito, G., Dos Santos, M. C., de Andrade, W. P. "Influence of mineral admixtures on the alkali-aggregate reaction", Cement and Concrete Research, 27(12), pp. 18991909, 1997.

https://doi.org/10.1016/S0008-8846(97)00206-8

[13] Ramlochan, T., Thomas, M., Gruber, K. A. "The effect of metakaolin on alkali-silica reaction in concrete", Cement and Concrete Research, 30(3), pp. 339-344, 2000 https://doi.org/10.1016/S0008-8846(99)00261-6

[14] Malvar, L. J., Cline, G. D., Burke, D. F., Rollings, R., Sherman, T. W., Greene, J. L. "Alkali-Silica Reaction Mitigation: State of the Art and Recommendations", ACI Materials Journal, 99(5), pp. 480-489, 2002.

[15] Lindgård, J., Thomas, M. D. A., Sellevold, E. J., Pedersen, B., Andiç-Çakır, Ö., Justnes, H., Rønning, T. F. "Alkali-silica reaction (ASR)-performance testing: Influence of specimen pre-treatment, exposure conditions and prism size on alkali leaching and prism expansion", Cement and Concrete Research, 53, pp. 68-90, 2013. https://doi.org/10.1016/j.cemconres.2013.05.017

[16] Mazarei, V., Trejo, D., Ideker, J. H., Isgor, O. B. "Synergistic effects of ASR and fly ash on the corrosion characteristics of RC systems", Construction and Building Materials, 153, pp. 647-655, 2017. https://doi.org/10.1016/j.conbuildmat.2017.07.097

[17] Jin, W., Meyer, C., Baxter, S. "Glascrete" - Concrete with Glass Aggregate, ACI Materials Journal, 97(2), pp. 208-213, 2000. https://doi.org/10.14359/825

[18] TSE "TS EN 197-1 Cement - Part 1: Composition, specification and conformity criteria for common cements", Turkish Standards Institution, Ankara, Turkey, 2012.

[19] Shi, C., Wu, Y., Shao, Y., Riefler, C. "Alkali-aggregate reaction expansion of mortar bars containing ground glass powder. Alkali aggregate reaction in concrete", In: Proceedings of the 12th International Conference on Alkali-Aggregate Reaction in Concrete, Beijing, China, 2004, pp. 789-795.

[20] Ercikdi, B., Külekci, G., Yılmaz, T. "Utilization of granulated marble wastes and waste bricks as mineral admixture in cemented paste backfill of sulphide rich tailings", Construction and Building Materials, 93, pp. 573-583, 2015. https://doi.org/10.1016/j.conbuildmat.2015.06.042

[21] TSE "TS EN 196-2 Method of testing cement - Part 2: Chemical analysis of cement", Turkish Standards Institution, Ankara, Turkey, 2013.

[22] Ramyar, K., Çopuroğlu, O., Andiç, Ö., Fraaij, A. L. A. "Comparison of alkali-silica reaction products of fly-ash or lithium-salt-bearing mortar under long-term accelerated curing", Cement and Concrete Research, 34(7), pp. 1179-1183, 2004. https://doi.org/10.1016/j.cemconres.2003.12.007 
[23] ASTM "ASTM C1260-94 Standard Test Method for Potential Alkali Reactivity of Aggregates (Mortar-bar method)", ASTM International, West Conshohocken, PA, USA, 1994. https://doi.org/10.1520/C1260-94

[24] du Plessis, A., Boshoff, W. P. "A review of X-ray computed tomography of concrete and asphalt construction materials", Construction and Building Materials, 199, pp. 637-651, 2019. https://doi.org/10.1016/j.conbuildmat.2018.12.049

[25] Afshinnia, K., Poursaee, A. "The potential of ground clay brick to mitigate Alkali-Silica Reaction in mortar prepared with highly reactive aggregate", Construction and Building Materials, 95, pp. 164-170, 2015.

https://doi.org/10.1016/j.conbuildmat.2015.07.155

[26] Farny, J. A., Kerkhoff, B. "Diagnosis and Control of AlkaliAggregate Reactions in Concrete", Portland Cement Association, Skokie, IL, USA, IS413, 2007.

[27] Bleszynski, R. F., Thomas, M. D. A. "Microstructural Studies of Alkali-Silica Reaction in Fly Ash Concrete Immersed in Alkaline Solutions", Advanced Cement Based Materials, 7, pp. 66-78, 1998. https://doi.org/10.1016/S1065-7355(97)00030-8

[28] Guo, S., Dai, Q., Sun, X., Xiao, X. "X-ray CT characterization and fracture simulation of ASR damage of glass particles in alkaline solution and mortar", Theoretical and Applied Fracture Mechanics, 92, pp. 76-88, 2017. https://doi.org/10.1016/j.tafmec.2017.05.014

[29] Hong, S.-Y., Glasser, F. P. "Alkali sorption by C-S-H and C-A-S-H gels Part II. Role of alumina", Cement and Concrete Research, 32, pp. 1101-1111, 2002.

https://doi.org/10.1016/S0008-8846(02)00753-6

[30] Abbas, A., Fathifazl, G., Fournier, B., Isgor, O. B., Zavadil, R., Razaqpur, A. G., Foo, S. "Quantification of the residual mortar content in recycled concrete aggregates by image analysis", Materials Characterization, 60, pp. 716-728, 2009.

https://doi.org/10.1016/j.matchar.2009.01.010
[31] Geng, G., Shi, Z., Leemann, A., Borca, C., Huthwelker, T., Glazyrin, K., Pekov, I. V., Churakova, S., Lothenbachb, B., Dähn, R., Wieland, E. "Atomistic structure of alkali-silica reaction products refined from X-ray diffraction and micro X-ray absorption data", Cement and Concrete Research, 129, Article No. 105958, 2020. https://doi.org/10.1016/j.cemconres.2019.105958

[32] Yang, S., Cui, H., Poon, C. S. "Assessment of in-situ alkali-silica reaction (ASR) development of glass aggregate concrete prepared with dry-mix and conventional wet-mix methods by X-ray computed micro-tomography", Cement and Concrete Composites, 90, pp. 266-276, 2018.

https://doi.org/10.1016/j.cemconcomp.2018.03.027

[33] Koenig, A. "Analysis of air voids in cementitious materials using micro X-ray computed tomography $(\mu \mathrm{XCT}) "$, Construction and Building Materials, 244, Article No. 118313, 2020. https://doi.org/10.1016/j.conbuildmat.2020.118313

[34] Si, R., Guo, S., Dai, Q., Wang, J. "Atomic-structure, microstructure and mechanical properties of glass powder modified metakaolin-based geopolymer", Construction and Building Materials, 254, Article No. 119303, 2020.

https://doi.org/10.1016/j.conbuildmat.2020.119303

[35] Kim, T., Alnahhal, M. F., Nguyen, Q. D., Panchmatia, P., Hajimohammadi, A., Castel, A. "Initial sequence for alkali-silica reaction: Transport barrier and spatial distribution of reaction products", Cement and Concrete Composites, 104, Article No. 103378, 2019.

https://doi.org/10.1016/j.cemconcomp.2019.103378

[36] Wei, J., Gencturk, B., Jain, A., Hanifehzadeh, M. "Mitigating alkali-silica reaction induced concrete degradation through cement substitution by metakaolin and bentonite", Applied Clay Science, 182, Article No. 105257, 2019. https://doi.org/10.1016/j.clay.2019.105257 